\title{
Early Development of Northeast Arctic Greenland Halibut (Reinhardtius hippoglossoides)
}

\author{
Anne Stene \\ Ålesund College \\ P.O. Box 5104, N-6021 Ålesund, Norway \\ Agnes C. Gundersen \\ Møre Research, Section of Fisheries \\ P. O. Box 5057, N-6021 Ålesund, Norway
}

Ole T. Albert

Norwegian Institute of Fisheries and Aquaculture Ltd.

P. O. Box 2511, N-9002 Tromsø, Norway

and

Kjell H. Nedreaas and Per Solemdal

Institute of Marine Research

P. O. Box 1870, Nordnes, N-5024 Bergen, Norway

\begin{abstract}
The early development of the Greenland halibut (Reinhardtius hippoglossoides) has not been described. This study presents some preliminary notes on the egg development of the Northeast Arctic Greenland halibut. Buoyancy and morphometric characteristics of artificially spawned eggs are compared with field sampled eggs, in order to identify these to species.

The eggs in the ovary of ripening females were large (about $4 \mathrm{~mm}$ ), transparent, almost equal in size and stuck to the walls of the ovary. In running, artificially spawned females the ovulated eggs were all easily released in one batch. This may indicate that Greenland halibut has a comparatively long period between each egg batch delivered.

Artificially spawned eggs of the Greenland halibut had a diameter varying from 3.3 to $4.2 \mathrm{~mm}$ and a neutral buoyancy in seawater of ca. $33 \%$ (c. $\left.5^{\circ} \mathrm{C}\right)$ during the first four days of development. During gastrulation the egg density increased until closure of blastopore. Eggs from field surveys had a diameter raging from 3.9 to $4.7 \mathrm{~mm}$ and a neutral buoyancy in seawater of $35.2 \%$ (ca. $5^{\circ} \mathrm{C}$ ). This corresponds to a density near $1.0279 \mathrm{~g} / \mathrm{cm}^{3}$. This density is found at depths around $650 \mathrm{~m}\left(34.9 \%\right.$ salinity and $\left.1.8^{\circ} \mathrm{C}\right)$ in the spawning area.
\end{abstract}

The eggs hatched after nearly two months of incubation at ca. $2^{\circ} \mathrm{C}$. The embryo seemed to hatch at a premature stage.

Key words: eggs, Greenland halibut, morphology, Northeast Atlantic

\section{Introduction}

The Greenland halibut (Reinhardtius hippoglossoides W.) has a wide arcto boreal distribution in the Atlantic and the Pacific oceans. According to Smidt (1969), spawning takes place around
Greenland from December to April in depths of 800-1 000 m. In the Barents Sea /Norwegian Sea, Hognestad (1969) reported spawning from April to July, while Fedorov (1971) indicated spawning mainly in October-January, and possibly year round. 
Eggs and larvae of this species have been observed in plankton tows around West Greenland, (Jensen, 1935; Smidt, 1969), West Iceland (Magnusson, MS 1977) and the Bering Sea (Bulatov, 1981). These observations indicate a bathypelagic distribution around 600 to $800 \mathrm{~m}$ depth, but eggs have also been registered in plankton nets in the upper $50 \mathrm{~m}$ (Smidt, 1969). The eggs were identified as Greenland halibut according to size, vitelline membrane and season. Eggs from the Northeast Arctic population were reported in the Barents Sea for the first time in December 1997 (Albert et al., MS, 1998).

This paper describes the early development of the North East Arctic Greenland halibut and a preliminary study on distribution of eggs and larvae in the water column. Because little is known concerning early development of Greenland halibut, the objective of this study was to document reliable identification characteristics of eggs and larvae. Since knowledge of vertical distribution is the first step in understanding the horizontal transport of fish eggs and larvae (Sundby, 1991), attempts were made to get an indication of egg buoyancy in order to confirm their distribution in the water column in later studies.

\section{Materials and Methods}

\section{Sampling}

Greenland halibut were sampled along the continental slope, west and north of Northern Norway. Four long line surveys were conducted each month from August to December. Two localities $\left(69^{\circ} 20^{\prime} \mathrm{N}\right.$ and $\left.70^{\circ} 20 \mathrm{~N}\right)$ were surveyed using 5000 to 6000 hooks in each of the following depths: $300-500 \mathrm{~m}, 500-700 \mathrm{~m}$ and $700-900 \mathrm{~m}$.

One trawl survey was conducted in January 1998 , where five localities $\left(70^{\circ} 20^{\prime} \mathrm{N}, 71^{\circ} 20^{\prime} \mathrm{N}\right.$, $72^{\circ} 40^{\prime} \mathrm{N}, 73^{\circ} 40^{\prime} \mathrm{N}, 74^{\circ} 40^{\prime} \mathrm{N}$ ) were investigated. Trawl hauls were made in $100 \mathrm{~m}$ depth intervals between $400-800 \mathrm{~m}$. During these surveys about 900 fishes were examined for sex and maturity, in order to make egg cultures for development studies. Maturity of females was determined according to size and transparency of the eggs (Nielsen and Boje, MS 1995). Males were classified as running, when sperm was released by a light pressure on the abdomen.

\section{Fertilization and incubation}

During the sampling period, only one running female $(70 \mathrm{~cm} / 3088 \mathrm{~g})$ was found at a depth of $700 \mathrm{~m}$ in January (of 189 females examined). The eggs (ca. 5 000) were easily released from the ovary, artificially fertilised when brought onboard (male: $50 \mathrm{~cm} / 949 \mathrm{~g}$ ), and incubated in static water, which was changed every second day. No antibiotics were added.

The temperature during development was 4$5^{\circ} \mathrm{C}$ for the first 5 days. Then the eggs were transferred to ca. $2^{\circ} \mathrm{C}$ for further development. This change in temperature was due to observed changes in buoyancy during development, starting in the surface-water at $4-5^{\circ} \mathrm{C}$ and then sinking during gastrulation. About 20 eggs were studied and photographed using a light microscope (Wild macrotube) every fourth day. Morphology, developmental stage, egg diameter $(\mathrm{mm})$ and larvae length $(\mathrm{mm})$ were observed and registered. Diameter of eggs are based on 110 observations.

\section{Plankton surveys}

Vertical plankton surveys were made in January with a MIK plankton sampler (Method, 1986) at depths from 800 to $50 \mathrm{~m}$. This sampler consists of a net $(1.5 \mathrm{~mm})$ attached to a ring with a diameter of $2 \mathrm{~m}$, equipped with a wireless "Scanmar" depth sensor. The speed of the trawl was 1.5 knots, after a fast descent (one hour down to $800 \mathrm{~m}$ ). Since this is an open sampler, the water volume filtered in each tow varied with depth. Eggs found in these surveys were kept alive at $4-5^{\circ} \mathrm{C}$.

\section{Buoyancy experiments}

Eggs from field surveys and 24 hour old artificially spawned eggs were transferred to seawater of different salinities for buoyancy studies. The seawater was salted with $\mathrm{NaCl}$ or diluted with distilled water to create different salinity values. Twenty to thirty eggs were placed in 9 graded glass columns of $500 \mathrm{ml}$ for 24 hours $\left(4-5^{\circ} \mathrm{C}\right)$ in salinities of 31 to $36 \%$. Aggregation of eggs in the middle of the column, was used as an indication of neutral buoyancy. The salinity and temperature data from this experiment were converted into density values and compared to density data from the CTD-probe onboard, in order to find an indication of vertical distribution of the eggs in the field. 
Due to a malfunction in the CTD-probe onboard the research vessel, temperature, density and salinity were measured with a standard aerometer/ densimeter. Hydrographical data referred to in the discussion are recorded with a CTD-probe in the same area in mid-November 1997 and mid-February 1998.

\section{Results and Discussion}

\section{Spawning}

Eggs observed in the ovary of ripe females, just prior to spawning, were transparent, almost equal in size (ca. $4 \mathrm{~mm}$ ) and stuck to the walls of the ovary. The eggs in the ovary of the running female were similar in size, but clearer and not attached to the ovary and were easily extruded with light pressure on the fish. In spent females the ovaries were slack, reddish and hollow with residual eggs.

No running female fish were observed in the long line surveys. This could be due to sampling techniques and lack of appetite during the spawning period. However, only one running female was found during the trawl survey in January. Most of the 189 female fish registered during this survey, were either just prior to spawning or had spawned. Difficulties in finding ripe Greenland halibut females are also reported in other investigations (Jensen, 1935).

It is not known whether Greenland halibut is a serial spawner, or release all eggs in one batch. Hognestad (1969) and Albert et al. (MS 1998) indicate a spawning period both in the winter and in the spring. Fedorov (1971) on the other hand discusses the possibility that spawning occurs year round. In spent females, small oocytes (ca. $0.5 \mathrm{~mm}$ ), difficult to observe, were found in the walls of the ovary, in addition to the residual eggs. Rønneberg et al. (MS 1998) identified those oocytes as a separate group not ready for spawning until the next spawning period. Few running females and even egg size in running and ripe fishes found in this study, also indicate a long period between each batch spawned or each spawning event.

\section{Early development}

Eggs observed in plankton tows have been identified as Greenland halibut in the light of size, a reddish-brown vitelline membrane and season. Eggs sampled from the field in this study did not have a reddish-brown membrane, but seemed identical to the artificially spawned eggs of the same developmental stage (Fig. 1A and Fig. 2G). The mean diameter of eggs from the field survey in the Barents Sea in January 1998 were $4.4 \mathrm{~mm}$ which is within the range of other investigations referred to in Table 1. The largest egg found in our investigation was $4.7 \mathrm{~mm}$. This is somewhat larger than maximum observations from other areas. In Atlantic halibut (Hippoglossus hippoglossus) significant differences in egg diameter have been reported between different areas and between sampling years at the same spawning location (Haug et al., 1984). Unfortunately, all investigations dealing with eggs of Greenland halibut are based on few observations (Table 1). It is therefore difficult to draw any conclusion concerning size of field eggs in this study.
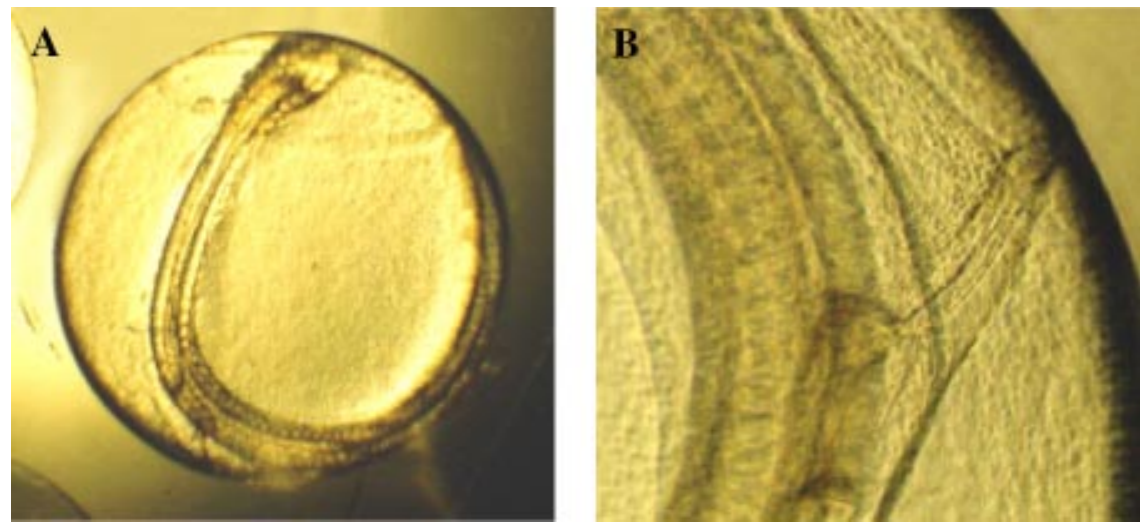

Fig. 1. Late stage egg (dm. $4.7 \mathrm{~mm})$ from field surveys in January 1998. (A) the egg, (B) the structure at the back of the developing embryo. 
TABLE 1. Sampling area, egg diameter (mean and range), sample size, depth indication, sampling period and references of relevant investigations dealing with early stages of Greenland halibut.

\begin{tabular}{|c|c|c|c|c|c|c|}
\hline Area & $\begin{array}{l}\text { Mean } \\
(\mathrm{mm})\end{array}$ & $\begin{array}{l}\text { Range } \\
(\mathrm{mm})\end{array}$ & Sample & $\begin{array}{l}\text { Depth } \\
\text { range }\end{array}$ & Month & References \\
\hline Bering Sea & 3.8 & $3.71-4.10$ & $11 \mathrm{eggs}$ & Above $3000 \mathrm{~m}$ & Feb-Mar & Bulatov, 1981 \\
\hline West Iceland & 4.01 & $3.83-4.17$ & $13 \mathrm{eggs}$ & About $850-1000 \mathrm{~m}$ & Mar & Magnusson, 1977 \\
\hline West Greenland & 4.0 & $3.8-4.3$ & $28 \mathrm{eggs}$ & $600 \mathrm{~m}$ wirelength & Mar-May & Smidt, 1969 \\
\hline Barents Sea & & & 6 eggs & Above $800 \mathrm{~m}$ & Dec & Albert et al., 1998 \\
\hline Barents Sea & 4.4 & $3.9-4.7$ & 7 eggs & Above $800 \mathrm{~m}$ & Jan & This investigation \\
\hline
\end{tabular}

The egg diameter of artificially spawned eggs from the Barents Sea was $3.7 \mathrm{~mm}$ (range 3.2-4.2 $\mathrm{mm}$ ). This is slightly smaller than measurements on field eggs from other areas. Smaller size of the artificially spawned eggs is also observed in Atlantic halibut (Lønning et al., 1982). This may be due to the fertilisation process and environmental conditions differing from that in the deep spawning area. Eggs from field surveys and artificially spawned eggs observed in this study did not have a reddish-brown membrane reported from other areas (Smidt, 1969; Magnusson, MS 1977; Bulatov, 1981). This difference can be a population characteristic or may be related to diet.

The early development of Greenland halibut has not been described in detail, but resembles that described for many pelagic fishes (Fridgeirsson, 1978). Only one drawing of a late stage Greenland halibut egg was found in the literature review (Smidt, 1969). Informative illustrations of the bathypelagic larvae are however made by Jensen (1935). Since little information exists concerning early development of Greenland halibut and because the early development resembles in many ways that of Atlantic and Pacific halibut, the egg and early larva is compared to these marine teleosts.

The unfertilized eggs were soft, with a wrinkled/striated surface. After contact with seawater and fertilization, the chorion hardened. In contrast to Pacific and Atlantic halibut (Forrester and Alderdice, 1973; Lønning et al., 1982), the striated appearance did not disappear until after gastrulation (Fig. 2A). Fertilization rate was $95 \%$.

Like Pacific and Atlantic halibut, the eggs of Greenland halibut also have a rather small pervitelline space (Fig. 2B), and cleave somewhat slower at $4-5^{\circ} \mathrm{C}$ than other pelagic fish eggs at the same temperature (Lønning, 1977). The first cleavage of Greenland halibut eggs started 10 hours after fertilization and cleaved every third hour forming the blastodisc with the surrounding periblast after 3 days (Fig. 2A). Gastrulation started five days after fertilization and lasted until closure of blastopore 20 days later (Fig. 2C and D).

The tissue layers and the embryo, starting to develop during gastrulation, were very thin and rather difficult to observe and photograph. Ten days after gastrulation eye bulbs started to develop and the ear primordia was easily seen (Fig. 2E). About five weeks after fertilization the embryo still had no pigmentation and like Atlantic halibut, the tail was bent (Fig. 2F). The structure observed at the back of the developing larvae was also present in late stage field eggs (Fig. 1B and Fig. 2G).

The eggs hatched 53 days after fertilization. The newly hatched larvae were ca. $6 \mathrm{~mm}$ long and seemed premature. Eyes and myotomes were visible but not pigmented (Fig. 2H). The heartbeat was difficult to observe. The large yolksack of the hatched embryo suggests a long period from hatching until first feeding. The larvae died 12 days after hatching probably due to bacterial infection, with most of its yolk sac still intact. Only eight eggs hatched. Helvik and Pittman (MS 1990) found that light exposure inhibited and delayed hatching and affected eye pigmentation in Atlantic halibut. During examination the Greenland halibut eggs were exposed to light for short periods. Artificially spawned Atlantic halibut eggs have also been reported to hatch at a seemingly premature stage, 18 days after fertilization at $5^{\circ} \mathrm{C}$ (Lønning et al., 1982). The longer period between fertilization and hatching in this study may be due to low incubation temperature. 

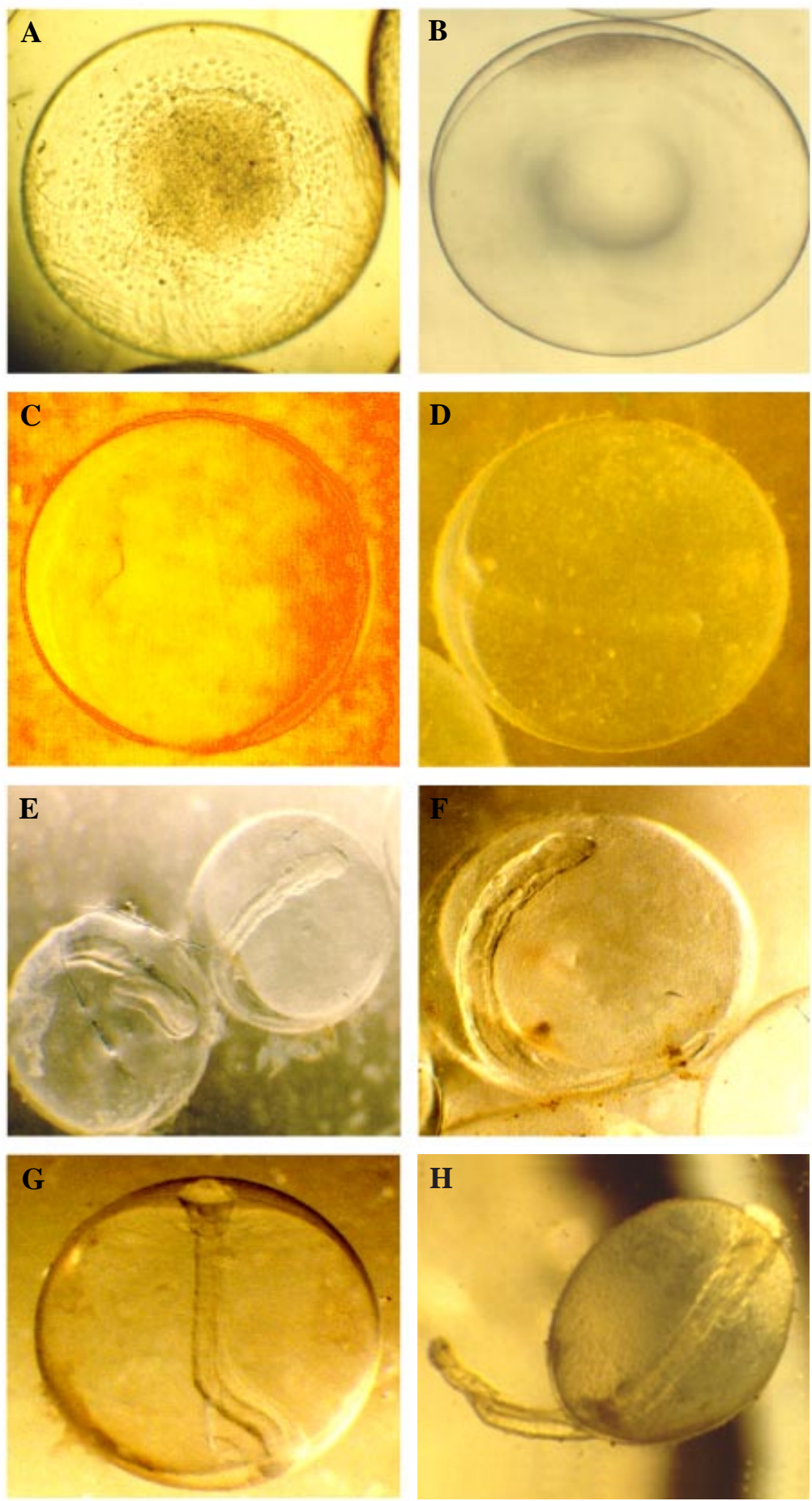

Fig. 2. Early developmental stages of Greenland halibut eggs and yolk sac larvae. (A) late blastula stage (4 days) with the surrounding periblast; (B) blastodisc with the surrounding pervitelline space (4 days); (C) Early gastrula stage (6 days), (D) Gastrulation finished (24 days); (E) lacking pigmentation and bent body during the latter part of organogenesis (37 days); (F) eye bulbs and ear primorda (30 days); (G) late stage egg with characteristic bending and structure at the back of the embryo (43 days); and (H) Newly hatched larvae (59 days old, 7 days after hatching). 


\section{Vertical distribution and density}

Plankton tows in the Barents Sea (January 1998) resulted in only 7 eggs of Greenland halibut. Three were found in a haul from $800 \mathrm{~m}$ depth, three were found in a haul from $600 \mathrm{~m}$, one was found in a haul from $200 \mathrm{~m}$ and no eggs were found in a haul from $50 \mathrm{~m}$ depth. In previous investigations, there is no documentation on exact depth distribution of Greenland halibut eggs in the water column (Table 1). The eggs of Greenland halibut have a small pervitelline space. This indicates no subjection to turbulence, and an adaptation to a bathypelagic distribution (Forrester and Alderdice, 1973).

The research vessels used in this study were not equipped with a plankton sampler that could be closed at different depths. Artificially fertilized eggs and eggs from plankton tows were therefor transferred to seawater of different salinity to get an indication of their natural buoyancy and vertical distribution in the sea. Artificially spawned eggs had neutral buoyancy in salinities of 31.2 to $34.0 \%$ o and sank in salinities below $31 \%$ at ca. $5^{\circ} \mathrm{C}$. During gastrulation the egg density increased, stabilizing at salinities of $35.5 \%$ (ca. $2^{\circ} \mathrm{C}$ ) after closure of blastopore (Fig. 3).

Large variations in neutral buoyancy salinity was observed in artificially spawned eggs. There are however expected to be large differences in the vertical distribution of the heaviest and lightest fraction of an egg population (Sundby, 1991). Steady decline in buoyancy during gastrulation is also reported from stripped Atlantic and Pacific halibut eggs (Magnor-Jensen and Waiwood, 1995) and (Forrester and Alderdice, 1973). Ability to regulate buoyancy through water loss and pervitelline space under varying environmental conditions seems to start during gastrulation (Kendall and Kim, 1989).

Density of fish eggs in a laboratory may be affected by light exposure and other diverging environmental conditions. It is therefore difficult to make direct comparison between the situation in the laboratory and in the sea. All eggs used in the buoyancy study were, however, in good condition and survived for several days until transferred to fixative.

The neutral buoyancy salinity of Greenland halibut eggs from field surveys was $35.2 \%$ at ca. $5^{\circ} \mathrm{C}$. This corresponds to a seawater density of ca. $1.0279 \mathrm{~g} / \mathrm{cm}^{3}$. This density is found at depths around 650 meters $\left(34.9 \%\right.$ salinity and $\left.1.8^{\circ} \mathrm{C}\right)$ in the spawning area and corresponds with their expected distribution in cold water around depths of 600 meters (Smidt, 1969). Further investigations on vertical distribution of Greenland halibut eggs must include a plankton sampler that can be closed after trawling at different depth.

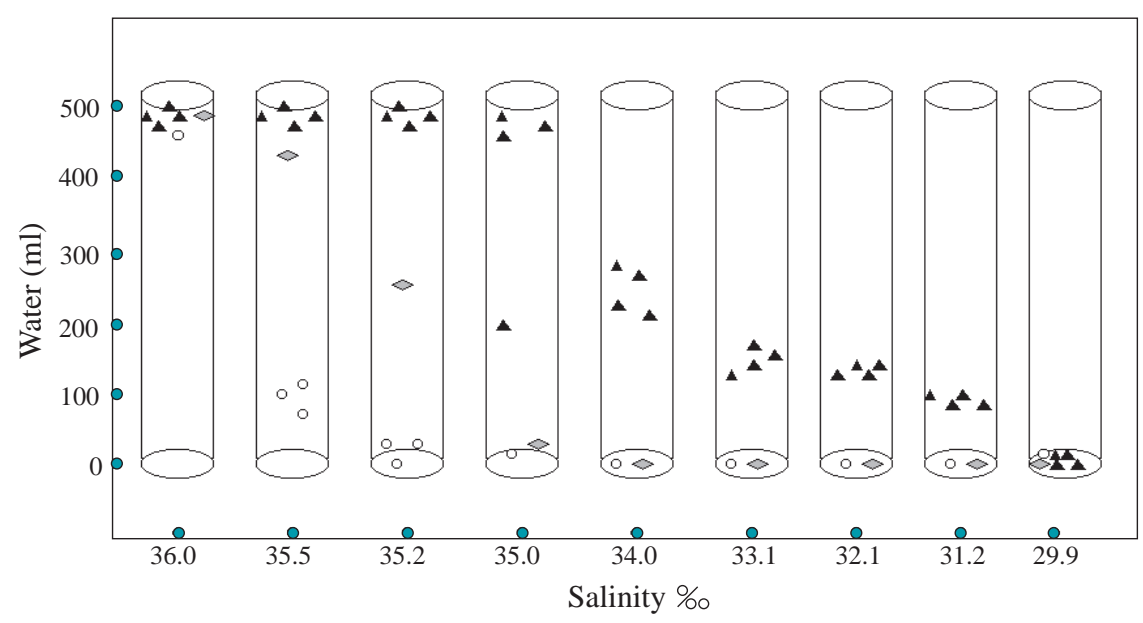

Fig. 3. Distribution of Greenland halibut eggs in graded glass columns with water of different salinities $\left(\right.$ ca. $\left.5^{\circ} \mathrm{C}\right)$. $\mathbf{\Delta}$ : New fertilized, artifically spawned eggs. $>$ : eggs from field surveys. o: late stage artificially spawned eggs $\left(\right.$ ca. $\left.2^{\circ} \mathrm{C}\right)$. Each symbol indicates ca. 5 eggs. 


\section{Acknowledgements}

The material was sampled by the Norwegian commercial long liner M/S Husby Senior by Institute of Marine Research in Bergen and Møre Research in Ålesund and the research vessel R/V Jan Mayen, conducted by Institute of Fisheries and Aquaculture in Troms $\emptyset$. We thank everybody that has been involved in the project, and the reviewers for constructive comments on the manuscript.

\section{References}

Albert, O. T., E. M. NILSEN, A. STENE, A. C. GUNDERSEN, and K. N. NEDERAAS. MS 1998. Spawning of the Barents Sea/Norwegian Sea Greenland halibut (Reinhardtius hippoglossoides). ICES C.M. Doc., No. O:22.

BULATOV, O. A. 1981. Distribution of egg and larvae of Greenland halibut, Reinhardtius hippoglossoides (Pleuronectidae), in the Eastern, Bering Sea. PINRO, Vladivostok.

FEDOROV, K. Y. 1971. The state of the gonads of the Barents Sea Greenland halibut (Reinhardtius hippoglossoides (Walbaum)) in connection with failure to spawn. J. Ichthyol., 11: 673-682.

FORRESTER, C. R., and D. F. ALDERDICE. 1973. Laboratory Observations on Early Development of the Pacific halibut. International Pacific Halibut Comm. Tech. Rep., 9: 1-15.

FRIDGEIRSSON, E. 1978. Embryonic development of five species of gadoid fishes in Icelandic waters. Rit Fiskdeildar, 5: 1-68.

HAUG, T, E. KJØRSVIK, and P. SOLEMDAL. 1984. Vertical distribution of Atlantic Halibut (Hippoglossus hippoglossus) eggs. Can. J. Fish. Aquat. Sci., 41: 789-805.

HELVIK, J. V., and K. PITTMAN. MS 1990. Light affects hatching, development and pigmentation in halibut (Hippoglossus hippoglossus L.). ICES C.M. Doc., No. F:40.

HOGNESTAD, P. T. 1969. Notes on Greenland halibut (Reinhardtius hippoglossoides Walbaum) in the eastern Norwegian Sea. Fiskeridirektoratets Havunders $\phi$ kelser, 15: 139-144.

JENSEN, A. S. 1935. The Greenland Halibut (Reinhardtius hippoglossoides (Walb.)). Its Development and Migration. Det Kongelige Danske Videnskabs Selskabs Skrifter, Naturvidenskapelig og mathematisk Afdeling, 9: 35 p.

KENDALL, A.W. Jr., and S. KIM. 1989. Buoyancy on Walleye pollock (Theragra chalocogramma) eggs in relation to water properties and movement in Shelikof Strait, Gulf of Alaska. Can. Publ. Fish. Aquat. Sci., 108: 169-180.

LØNNING, S. 1977. Effects of crude Ekofisk oil and oil products on marine fish larvae. Astarte, 10: 3747.

LØNNING, S., E. KJØRSVIK, T. HAUG, and B. GULLIKSEN. 1982. The early development of the halibut Hippoglossus hippoglossus (L) compared with other marine teleosts. Sarsia, 67(2): 85-92.

MAGNOR-JENSEN, A., and K. G. WAIWOOD. 1995. The effect of light exposure on buoyancy of halibut eggs. J. Fish. Biol., 47: 18-25.

MAGNUSSON, J. V. MS 1977. Notes on the eggs and larvae of Greenland halibut at Iceland. ICES C.M. Doc., No. F:47.

METHOD, R. D. 1986. Frame trawl for sampling pelagic, juvenile fish. Calif. Coop. Oceanic Fish. Invest. Rep., 27: 267-278.

NIELSEN, J. G., and J. BOJE. MS 1995. Sexual maturity of Greenland halibut based on visual and histological observations. NAFO SCR Doc., No. 18, Serial No. $\mathrm{N} 2525,7 \mathrm{p}$.

RØNNEBERG, J. E., A. C. GUNDERSEN, and J. BOJE. MS 1998. Fecundity of Greenland halibut (Reinhardtius hippoglossoides) in the East Greenland waters. ICES C.M. Doc., No. O:26.

SMIDT, E. L. B. 1969. The Greenland halibut, Reinhardtius hippoglossoides (Walb.), Biology and Exploitation in Greenland Waters. Medd. Dan. Fisk.Havunders., 6(4): 79-147.

SUNDBY, S. 1991. Factors affecting the vertical distribution of eggs. In: Havforsknings instituttets egg of larveprogram. Fiskeridirektoratet (ed.). ISBN 82-7461-021-0. 